Archaeologia Historica Polona tom 25, 2017, ISSN 1425-3534

\title{
Późnośredniowieczne piece produkcyjne z grodziska \\ Piotrówka w Radomiu - możliwości interpretacji
}

\author{
Late medieval production kilns from stronghold \\ Piotrówka in Radom - possibilities of interpretation
}

Zarys treści. W trakcie badań wykopaliskowych prowadzonych w latach 60. XX wieku na grodzisku Piotrówka w Radomiu rozpoznano między innymi relikty glinianych i ceglanych pieców o zbliżonych rozmiarach i owalnym planie podstawy. Odkrywcy określili ich chronologię na schyłek średniowiecza i uznali za pozostałość pieców do wytopu żelaza. Cały zespół miał jakoby stanowić ślady „ubogiej osady hutniczej”, wegetującej na opuszczonym na początku XIV wieku grodzie. Na pozostałości kolejnych pieców natrafiono podczas badań prowadzonych w latach 2010-2013. Jako, że nie stwierdzono w ich obrębie ani otoczeniu śladów wskazujących jednoznacznie na związek z wytopem żelaza, kwestia interpretacji funkcji pieców została ponownie otwarta. Wyniki analiz pozwalają przypuszczać, że opisywane obiekty to piece piekarskie wchodzące w skład zaplecza gospodarczego radomskiego zamku.

Słowa kluczowe: piece piekarskie, późne średniowiecze, Radom.

Badania radomskiego zespołu osadniczego, którego głównym elementem jest grodzisko na Piotrówce, trwają już ponad 50 lat (ryc. 1). Rozpoczęły się u schyłku lat 50. XX wieku, a w pierwszej dekadzie obecnego stulecia, po przeszło 30-letniej przerwie, zostały podjęte na nowo (m.in. Kierzkowska-Kalinowska 1970; Fuglewicz 2013; Trzeciecki 2013; 2015 - w cytowanych pracach dalsza literatura). Choć ich wyniki dalekie są jeszcze od pełnego opracowania, można stwierdzić, że zrewolucjonizowały one naszą wiedzę o pierwszych pięciu wiekach historii Radomia, nieudokumentowanych w źródłach pisanych. Znaczenie tych badań wykopaliskowych wykracza jednak poza skalę lokalną, bowiem zgromadzone 


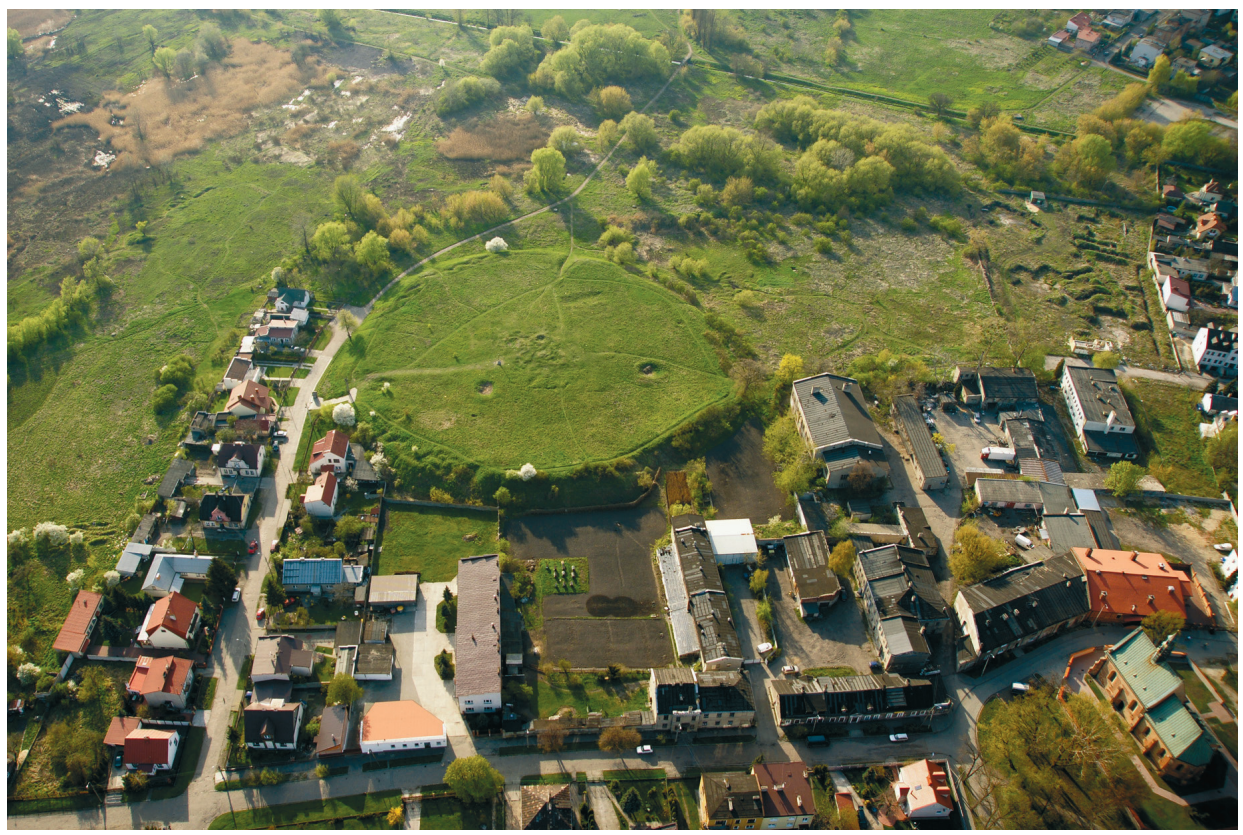

Ryc. 1. Grodzisko Piotrówka w Radomiu. Widok z góry (fot. D. Krasnodębski)

Fig. 1. Stronghold Piotrówka in Radom. Aerial view (photo by D. Krasnodębski)

w ciągu kolejnych sezonów badawczych materiały stanowią znakomitą bazę źródłową do studiów nad ekologią, gospodarką i strukturą społeczną niewielkiego, ze wszech miar typowego ośrodka „średniego szczebla” państwa piastowskiego, ewoluującego od wczesnośredniowiecznej siedziby władzy terytorialnej z podporządkowanąjej siecią osad do miasta komunalnego, stanowiącego już samodzielną jednostkę gospodarczą i administracyjną.

W trakcie kilkudziesięciu lat ewoluowały także zainteresowania, metody analiz i kierunki interpretacji. Badania millenijne zdominowała narracja „o początkach”, które także w przypadku Radomia miały sięgać w głąb okresu plemiennego. Te z ostatnich lat ukierunkowane są na całościowe postrzeganie zjawisk składających się na dzieje i współczesność Radomia oraz interpretowanie ich w kategoriach kształtowania się specyficznego dla tego miejsca krajobrazu kulturowego (Auch, Bugaj, Trzeciecki 2012). Jednym z jego istotnych, a niedostrzeganych wcześniej elementów są relikty specyficznych urządzeń produkcyjnych odkryte podczas badań na grodzisku Piotrówka.

Prace wykopaliskowe na grodzisku objęły obszar o łącznej powierzchni 20 arów (5 arów w latach 1959-1971 i 15 w latach 2010-2013). W ich wyniku rozpoznano sekwencję warstw i obiektów, które poświadczają użytkowanie tego miejsca od wczesnej epoki żelaza aż po czasy współczesne. Pozyskano dziesiątki tysięcy źródeł ruchomych, począwszy od masowych znalezisk - naczyń ceramicznych 
i kości zwierzęcych po elementy uzbrojenia, ozdoby czy monety. Stwierdzono, że okres najbardziej intensywnego zasiedlenia tego miejsca wiązał się z budową grodu na początku XI wieku. Obiekt użytkowany był do połowy XIV wieku, kiedy to siedziba kasztelana przeniesiona została do zamku wybudowanego w mieście lokowanym przez Kazimierza Wielkiego. Teren grodziska nie został jednak całkowicie opuszczony, w latach 1791-1812 funkcjonował tam cmentarz komunalny, a po połowie XIX wieku rosyjska prochownia. Od początku XX stulecia Piotrówka była niszczona przez rabunkową eksploatację piasku, zahamowaną dopiero pod koniec lat 50. wraz z początkiem badań archeologicznych i objęciem terenu całego zespołu osadniczego ochroną prawną (Auch, Trzeciecki 2011; Auch, Bugaj, Trzeciecki 2012; Fuglewicz 2013, s. 18 i nn.; Trzeciecki, Solarska 2013; Trzeciecki 2013, s. 26-31).

Już w pierwszym wykopie założonym na grodzisku w 1959 roku natrafiono na relikty dwóch wolno stojących kamienno-glinianych pieców. W trakcie kolejnych sezonów dokumentowano analogiczne konstrukcje, zawsze występujące w późnośredniowiecznym kontekście (ryc. 2); łącznie w latach 1959-1971 odkryto 12 pieców. Ich rozkład w badanych strefach był stosunkowo równomierny. W wykopie nr 1/1959 zadokumentowano pięć takich obiektów, w wykopie nr 2/1962 - trzy, w wykopie nr 4/1970 - cztery (Kierzkowska-Kalinowska 1973). Jako, że głównym przedmiotem zainteresowania były wówczas wczesnośredniowieczne poziomy użytkowe grodziska, piece dokumentowano dość pobieżnie. Najbardziej szczegółowo opisywane zostały obiekty odsłonięte w 1959 roku. Jeszcze w trakcie prac wykopaliskowych odkrywcy określili ich chronologię na schyłek średniowiecza i zasugerowali związek z wytopem żelaza. To datowanie i interpretacja były schematycznie przenoszone na kolejne obiekty, dokumentowane coraz bardziej pobieżnie, najczęściej w postaci planu na poziomie wyróżnienia.

Datowanie zespołu pieców na XIV-XV wiek i hipoteza o ich hutniczym przeznaczeniu, sformułowane we wstępnych sprawozdaniach z badań, zostały podtrzymane w publikacjach podsumowujących ich wyniki. Ewa Kierzkowska-Kalinowska, autorka badań, wiązała obiekty z okresem po likwidacji grodu na Piotrówce w połowie XIV wieku. Obszar ten miał wówczas znaleźć się na peryferiach nowego lokacyjnego Radomia, a na grodzisku wegetować miała „uboga osada hutnicza”, pracująca na potrzeby miasta (Kierzkowska-Kalinowska 1966, s. 212-213; 1973; 1979, s. 30-31; por. też Fuglewicz 2013, s. 99-100).

Na relikty kolejnego pieca natrafiono podczas badań prowadzonych w latach 2010-2013, w wykopie nr 8/2012 (Trzeciecki, Solarska 2013). Od obiektów odkrywanych w latach 60. XX wieku odróżniała go ceglana konstrukcja ścian. Niestety, ani w jego wnętrzu, ani w otoczeniu nie natrafiono na znaleziska, które mogłyby stanowić przesłanki do ustalenia pierwotnej funkcji. W wyniku przeprowadzonej wówczas kwerendy dokumentacji i znalezisk ze starszych badań uznano kwestię interpretacji tych znalezisk za ponownie otwartą. 


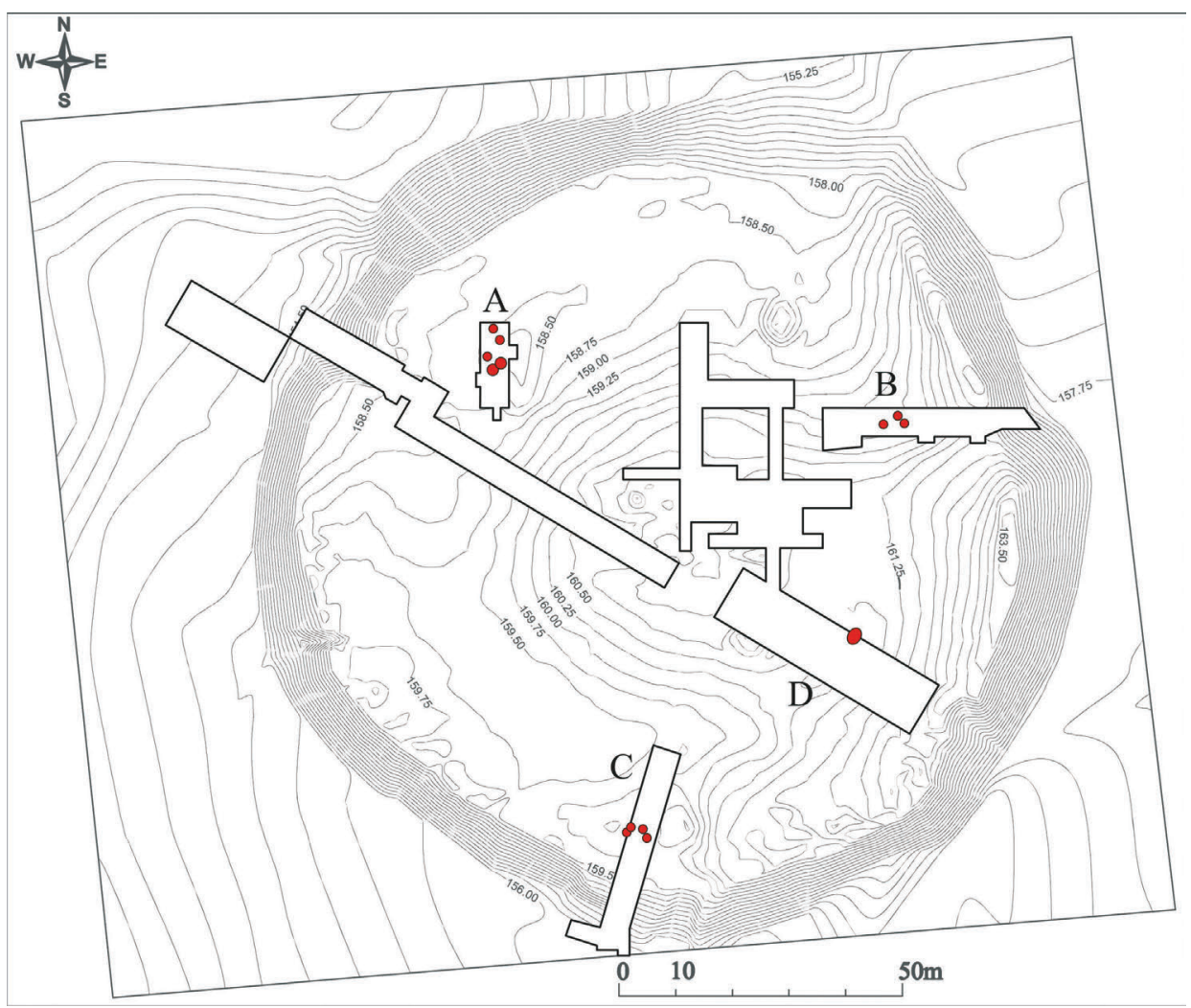

Ryc. 2. Grodzisko Piotrówka w Radomiu. Plan warstwicowy z lokalizacją reliktów pieców: A - wykop nr 1/1959, B - wykop nr 2/1962, C - wykop nr 4/1970, D - wykop nr 8/2012 (oprac. M. Trzeciecki)

Fig. 2. Stronghold Piotrówka in Radom. Contour plan with location of remains of kilns: A - trench No. 1/1959, B - trench No. 2/1962, C - trench No. 4/1970, D - trench No. 8/2012 (edited by M. Trzeciecki)

Największą liczbą danych dotyczących form i konstrukcji dysponujemy dla dwóch, położonych obok siebie pieców, odkrytych w wykopie 1/1959 i oznaczonych wówczas jako obiekty nr 4 i 5 ${ }^{1}$. W trakcie ich eksploracji wykonano dokumentację rysunkową kolejnych poziomów rozbieranych ścianek i usuwanych warstw klepiska oraz przekrojów przez konstrukcje, sporządzono opis obiektów, a także dokumentację fotograficzną (ryc. 3). Oba piece były zbliżone do siebie pod względem formy i parametrów. Zachowały się ich podstawy oraz dolne partie

${ }^{1}$ Dane dotyczące pieców odkrytych w latach 60 . XX wieku pochodzą przede wszystkim z analizy dokumentacji rysunkowej, sprawozdań oraz polowych inwentarzy znalezisk z badań E. Kierzkowskiej-Kalinowskiej, zachowanej w archiwum Muzeum im. Jacka Malczewskiego w Radomiu. Kwerendy i opracowanie wykorzystanych tu informacji były możliwe dzięki życzliwości i pomocy Małgorzaty Cieślak-Kopyt, kierującej Działem Archeologii w tym muzeum. 


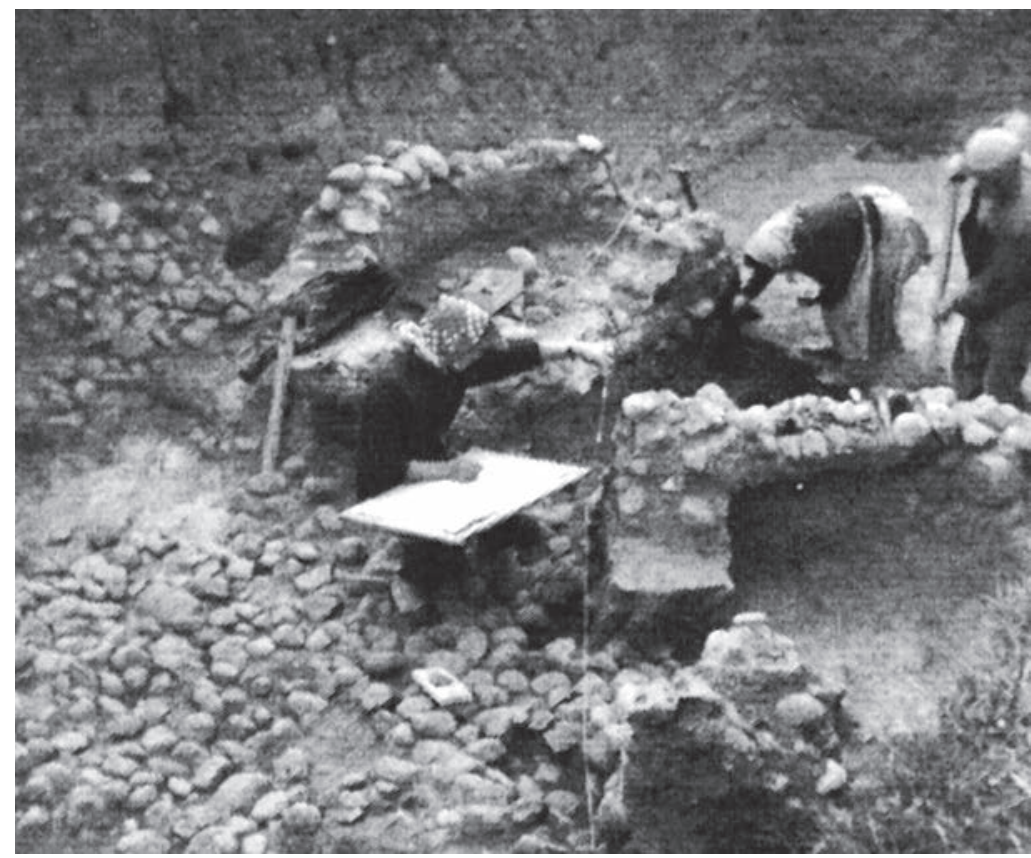

Ryc. 3. Grodzisko Piotrówka w Radomiu. Wykop nr 1/1959 - piece w trakcie eksploracji (wg Fuglewicz 2013)

Fig. 3. Stronghold Piotrówka in Radom. Trench No. 1/1959 - kiln during exploration (after Fuglewicz 2013)

ścianek, do wysokości 0,3-0,4 m. Wzniesiono je na bruku wykonanym z kilku warstw drobnych i średnich otoczaków granitowych. Na nim spoczywało gliniane klepisko, stanowiące poziom użytkowy komór pieców. Miały one plan zbliżony do okręgu, średnica komór wynosiła 1,5-1,6 m. Otaczały je ściany grubości 0,3-0,4 m, zbudowane z warstw dużych i średnich otoczaków przekładanych warstwami gliny. W obiekcie nr 4 wlot do komory pieca znajdował się od północy, a w obiekcie nr 5 - od północnego wschodu. Szerokość wlotów wynosiła około 0,4 m, osłaniające je ścianki wysunięte były przed lico ściany pieca na około 0,3 m. Część bruku, przylegająca bezpośrednio od północy do pieca nr 4, także przykryta była glinianym klepiskiem. Oba urządzenia najprawdopodobniej nie funkcjonowały równocześnie, bowiem z zachowanej dokumentacji rysunkowej wynika, że otwór wlotowy obiektu nr 5 był zasłonięty ścianą pieca nr 4, co wskazywałoby na następstwo chronologiczne bez zmiany formy i funkcji obiektów (ryc. 4). Wedle opisu w sprawozdaniu z badań, relikty pieców przykrywała warstwa brunatnego humusu z dużą ilością kamieni i przepalonej gliny - pochodzących zapewne z destrukcji ścian obiektów - oraz kawałków zwęglonego drewna. W zasypisku pieca nr 5 natrafiono na „bardzo dużo” brył żużla żelaznego oraz „stłuczkę szklaną” - przede wszystkim fragmenty szyb okiennych (Kierzkowska, Kierzkowski 1960). 


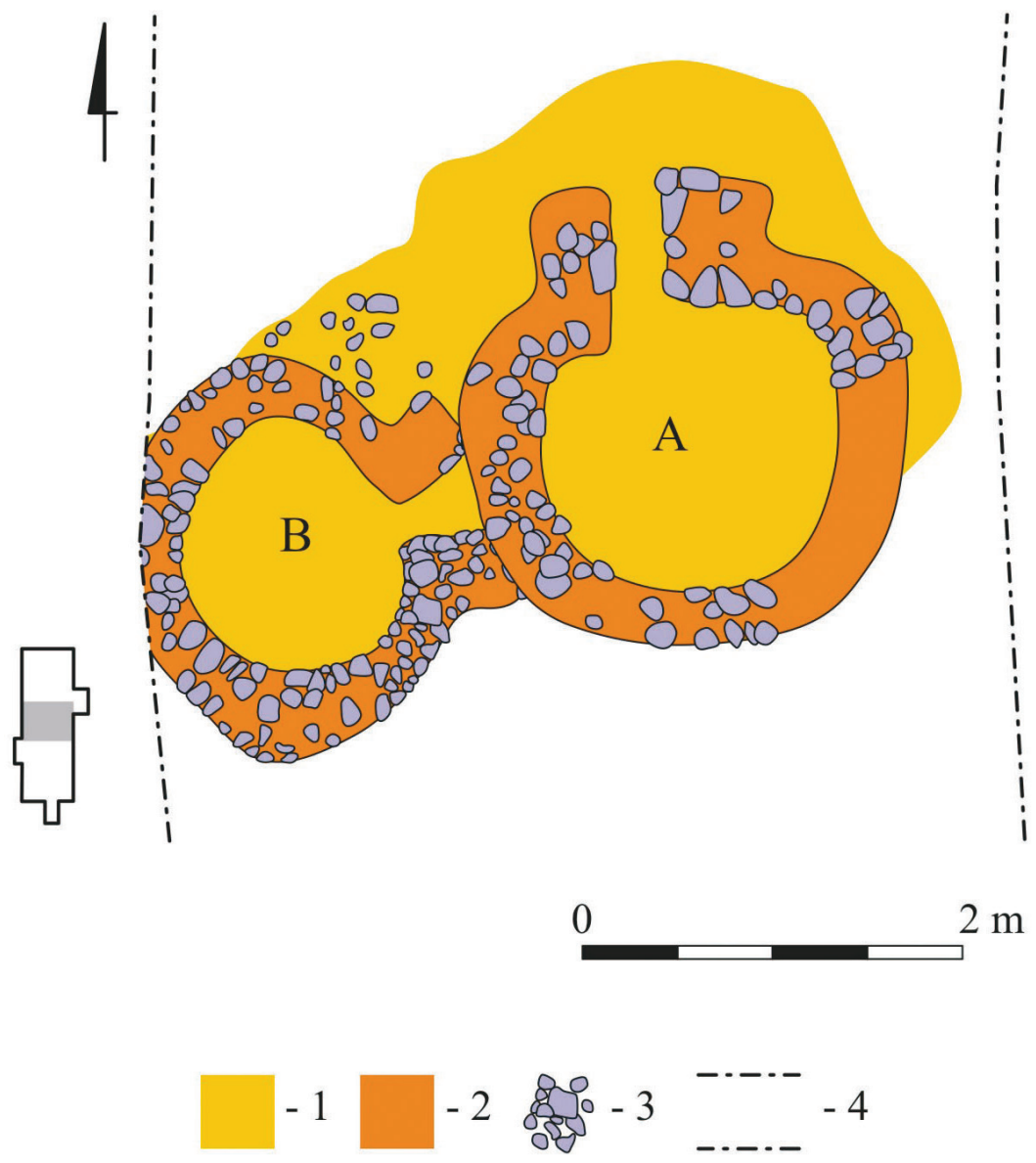

Ryc. 4. Grodzisko Piotrówka w Radomiu. Wykop nr 1/1959 - piece nr 4 (A) i 5 (B). 1 - gliniane klepisko podstawy pieców, 2 - gliniane ściany pieców, 3 - kamienie, 4 - granice wykopu (oprac. M. Trzeciecki)

Fig. 4. Stronghold Piotrówka in Radom. Trench No. 1/1959 - kilns Nos. 4 (A) and 5 (B). 1 - clay floor of kilns' foundations, 2 - clay walls of kilns, 3 - stones, 4 - boundary of trench (edited by M. Trzeciecki)

W końcowym sprawozdaniu, sporządzonym w 1973 roku, informacje o dużych ilościach żużla żelaznego pojawiły się także przy opisach pozostałych pieców (Kierzkowska-Kalinowska 1973).

Nie dysponujemy, niestety, równie szczegółowymi opisami pozostałych trzech pieców odkrytych w wykopie 1/1959. Zachował się jedynie schematyczny plan zbiorczy dokumentujący trzy owalne skupiska przepalonej gliny i kamieni o średnicy około 1,5 m każde. Jeszcze mniej informacji dotyczy pieców odsłoniętych 
w wykopie nr 2/1962. W sprawozdaniu pojawiła się informacja o jednym tego rodzaju obiekcie, owalnym, o średnicy równej około 1,5 m, odsłoniętym w sąsiedztwie reliktów spalonego budynku drewnianego datowanego na XIV-XV wiek (Kierzkowska-Kalinowska 1963). W końcowym sprawozdaniu z badań znalazły się wzmianki o dwóch kolejnych piecach, potwierdzone przez zachowane plany zbiorcze odnośnych odcinków wykopu z widocznymi kolistymi strukturami, złożonymi z przepalonej gliny otaczającej skupiska kamieni (Kierzkowska-Kalinowska 1973).

Równie niewielki jest zasób informacji dotyczących pieców odkrytych w wykopie nr 4/1970, oznaczonych jako obiekty nr 1, 2, 3 i 4. Zachował się plan zbiorczy części wykopu, dokumentujący obiekty na poziomie wyróżnienia oraz kilka planów obiektu nr 1 na kolejnych etapach eksploracji. Opis zawarty w sprawozdaniu z badań jest lakoniczny, dowiadujemy się jedynie, że wszystkie obiekty miały plan owalu o średnicy około 1,5 m (Kierzkowska-Kalinowska 1971). Analiza dokumentacji rysunkowej wskazuje, że w pełnym zarysie odsłonięto jedynie obiekty nr 1 i 2 (ryc. 5), pozostałe jedynie w części przy zachodnim profilu wykopu. Obiekt nr 4 był cięty przez obiekt nr 3, ponadto poziom użytkowy obu pieców został w dużej części zniszczony przez wkop pod pochówek z XVIII-wiecznego cmentarza.

Obiekt nr 1 - najokazalszy i najlepiej zadokumentowany - miał plan zbliżonego do czworoboku i wymiary około 1,3×1,6 m, dłuższą osią zorientowany był na linii północ-południe. Podstawę pieca tworzyły dwie warstwy otoczaków przekładane gliną i przykryte glinianym, silnie przepalonym klepiskiem, ze ścian zachowała się jedynie pierwsza warstwa kamieni spajanych gliną, o szerokości 0,4-0,5 m. Wlot komory najprawdopodobniej znajdował się od północy, w nieeksplorowanej części wykopu, pozostawionej jako świadek profilowy. Obiekt nr 2 zachował się w nieco gorszym stanie; miał owalny plan, wymiary komory były równe około 0,8×1,4 m, grubość ścian wynosiła najprawdopodobniej 0,3-0,5 m. Dno komory stanowiło gliniane klepisko, być może ułożone na warstwie kamieni; z konstrukcji ścian zachowała się warstwa gliny z pojedynczymi kamieniami najniższej warstwy. Zadokumentowany na rysunku zasięg warstwy silnie wyżarzonej polepy wskazuje, że otwór wlotowy znajdował się najprawdopodobniej od północnego wschodu, a jego średnica nie przekraczała 0,4-05 m. Piece odsłonięto w warstwie szaro-brunatnego humusu, z opisu w sprawozdaniu wynika, że analogiczne depozyty znajdowały się powyżej.

Odmienną konstrukcję miał piec, na który natrafiono w wykopie nr 8/2012, oznaczony jako obiekt nr 10; odsłonięto jedynie jego część przy północnym profilu wykopu (ryc. 6). Na tej podstawie można stwierdzić, że obiekt miał plan wydłużonego owalu o szerokości około 1,5 m i długości nie mniejszej niż 1,8 m. Został wzniesiony bezpośrednio na stropie warstwy szaro-brunatnego humusu. Dno komory pieca stanowiła warstwa zbitej, lekko przepalonej gliny o miąższości 


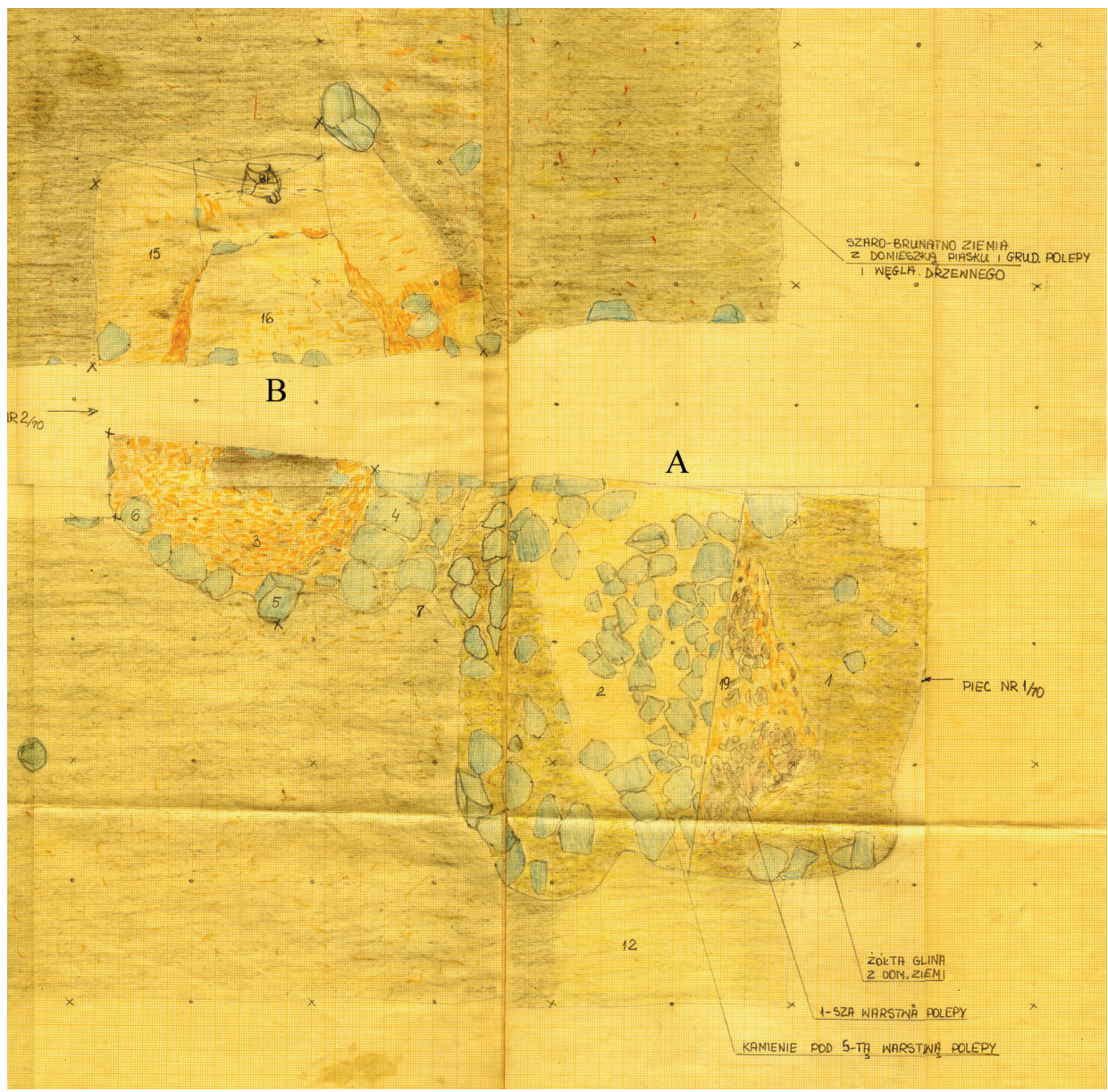

Ryc. 5. Grodzisko Piotrówka w Radomiu. Wykop nr 4/1970 - piece nr 1 (A) i 2 (B) (rysunek polowy z archiwum Muzeum im. Jacka Malczewskiego w Radomiu)

Fig. 5. Stronghold Piotrówka in Radom. Trench No. 4/1970 - kilns Nos. 1 (A) and 2 (B) (field drawing from the archives of the Jacek Malczewski Museum in Radom)

około 0,1 m, ułożona na ówczesnym poziomie użytkowania terenu. Ścianki pieca, silnie zniszczone, zwłaszcza w południowej części, wykonano z cegieł układanych poziomo i łączonych gliną, o wymiarach: 263-265×132-143×900-940 mm. Od zewnątrz cegły dodatkowo obłożone były warstwą drobnych kamieni, także spajanych glina. Nie natrafiono na destrukty ścianek pieca, jego relikty przykrywała niwelacyjna warstwa szarego humusu z licznymi fragmentami wczesnoi późnośredniowiecznych naczyń oraz kości zwierzęcych. Analiza stratygrafii otoczenia obiektu wskazuje, że po wyłączeniu go z użytkowania ściany rozebrano, teren wokół zniwelowano i przykryto wyrównawczą warstwą ziemi, na której 


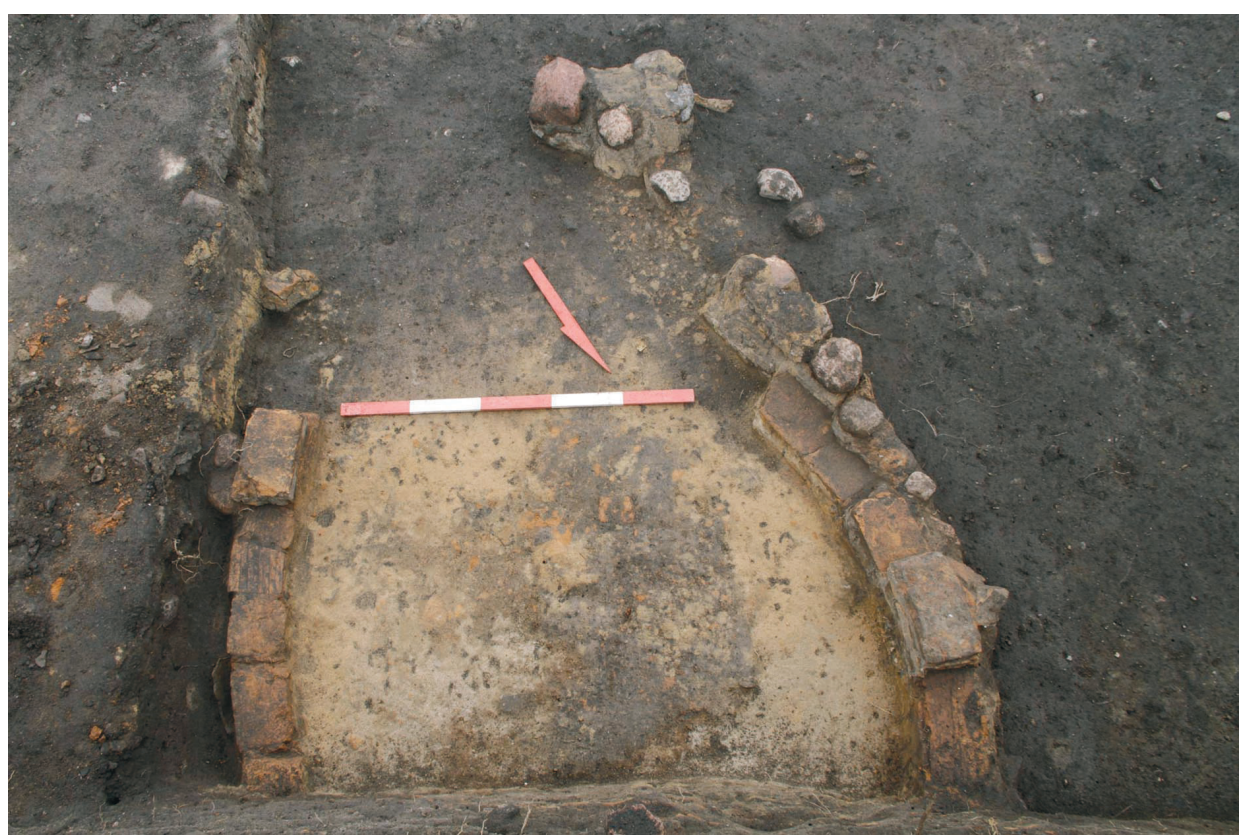

Ryc. 6. Grodzisko Piotrówka w Radomiu. Wykop nr 8/2012, obiekt nr 10 - widok ogólny (fot. K. Solarska)

Fig. 6. Stronghold Piotrówka in Radom. Trench No. 8/2012, feature No. 10 - general view (photo by K. Solarska)

w późniejszym okresie ułożono nieregularny kamienny bruk. Na podstawie danych stratygraficznych i datowania znalezisk relikty pieca zostały powiązane z fazą VII, której chronologię określono na okres między połową XIV a schyłkiem XV wieku. Z fazą tą związane są także pozostałości kilku dużych, podpiwniczonych budynków szkieletowych odsłoniętych w sąsiedztwie opisywanego obiektu (Trzeciecki, Solarska 2013, s. 66-67).

Analiza porównawcza danych dotyczących chronologii obiektów odkrytych w latach 1959-1970 i w 2012 pozwala zaliczyć je do tego samego horyzontu chronologicznego, związanego z likwidacją fortyfikacji grodu i zmianą funkcji badanego miejsca. Warto przy tym zauważyć, że wstępne datowanie zaproponowane w latach 60. XX wieku nie odbiega znacząco od ustaleń dokonanych prawie 50 lat później. Odmiennie natomiast w kontekście nowych odkryć przedstawia się interpretacja funkcji grodziska w okresie między połową XIV a schyłkiem XV wieku. Jak już wspomniano, z fazą tą wiązano opisane wyżej piece oraz „domostwo” odkryte w wykopie nr 2/1962. Obiekty te uznano za relikty „ubogiej osady hutniczej”.

Na możliwość nowej interpretacji wskazały dopiero wyniki badań prowadzonych w latach 2010-2013, które dostarczyły danych umożliwiających odtworzenie 
przemian przestrzennych i funkcjonalnych tego terenu między XI a XIX wiekiem (Auch, Bugaj, Trzeciecki 2012, s. 26-27; Auch, Solarska, Trzeciecki 2013; Trzeciecki, Solarska 2013, s. 65-68; Trzeciecki 2013, s. 34-36). Stwierdzono przede wszystkim, że porzucenie grodu wiązało się ze spaleniem i częściową niwelacją jego fortyfikacji oraz planową rozbiórką stosunkowo gęstej wówczas zabudowy majdanu. Zapewne przez krótki okres czasu grodzisko pozostawało puste, następnie jego wnętrze wyrównano, wykorzystując do tego częściowo zniwelowane nawarstwienia wczesnośredniowieczne. Na tak przygotowanym terenie pojawiła się zabudowa złożona z obszernych, w większości podpiwniczonych, drewnianych budynków o ścianach wykonanych w konstrukcji szkieletowej (ryc. 7). Wymiary zagłębionych w ziemię partii tych obiektów wahały się między $5 \times 5$ a $6 \times 8 \mathrm{~m}$. We wnętrzach niektórych piwnic zachowały się ślady ramowych konstrukcji szalunku ścian lub ślady ich demontażu, niekiedy też warstwy przepalonej gliny i drewna, pochodzące z destrukcji ścian nadziemnych. Nie przetrwały natomiast podwaliny ścian nadziemnych budynków, co związane było z licznymi niwelacjami terenu i wkopami grobowymi XVIII-wiecznego cmentarza. Analiza wyników badań i dokumentacji z badań wykopaliskowych prowadzonych w latach 60. XX wieku pozwoliła na wyróżnienie co najmniej 17 tego rodzaju obiektów. Paradoksalnie, jednym z najlepiej zachowanych było „domostwo" odsłonięte w 1962 roku, w pobliżu jednego z opisanych tu pieców. Nie wszystkie funkcjonowały w tym samym czasie, bezpośrednie następstwo stratygraficzne najlepiej udokumentowane jest dla trzech budynków odsłoniętych w 2013 roku w środkowej części majdanu.

Z wypełnisk budynków oraz z towarzyszących im warstw użytkowych pochodzą wyjątkowo bogate zespoły znalezisk. Obok bardzo licznych kości zwierzęcych pozyskano duże serie naczyń tzw. tradycyjnych, wypalonych w atmosferze redukcyjnej oraz fragmenty dzbanów kamionkowych i ceglastych szkliwionych. Znaczne liczebnie grupy stanowiły też elementy rzędu końskiego - ostrogi i wędzidła, militaria - noże bojowe, topory, czekan, części puginałów, groty bełtów kusz, wyroby z kości - pionki do gry, kościana okładzina z ozdobnym napisem, piszczałka, a także metalowe elementy stroju i ozdoby oraz monety. Minimalny był natomiast udział znalezisk mogących wskazywać na prowadzenie wówczas na grodzisku jakiejkolwiek działalności produkcyjnej. Wskazać tu można na kilkanaście fragmentów żużla żelaznego i bryłki stopionego ołowiu, pozyskane z zasypisk piwnic. Nie mamy przy tym pewności, czy nie wystąpiły one na tzw. wtórnym złożu, bowiem stosunkowo duża liczba żużli żelaznych i naczyń ze śladami przetapiania surowca uzyskanego z pieców dymarskich pochodziła z nawarstwień użytkowych grodu, z faz datowanych na XII i 1. połowę XIII wieku, niszczonych przez wkopy pod opisane tu budynki.

Przedstawione powyżej ustalenia nakazywały podjąć próbę weryfikacji zarówno funkcji proponowanej dla pieców odkrytych w latach 60., jak i tezy o „ubogiej 


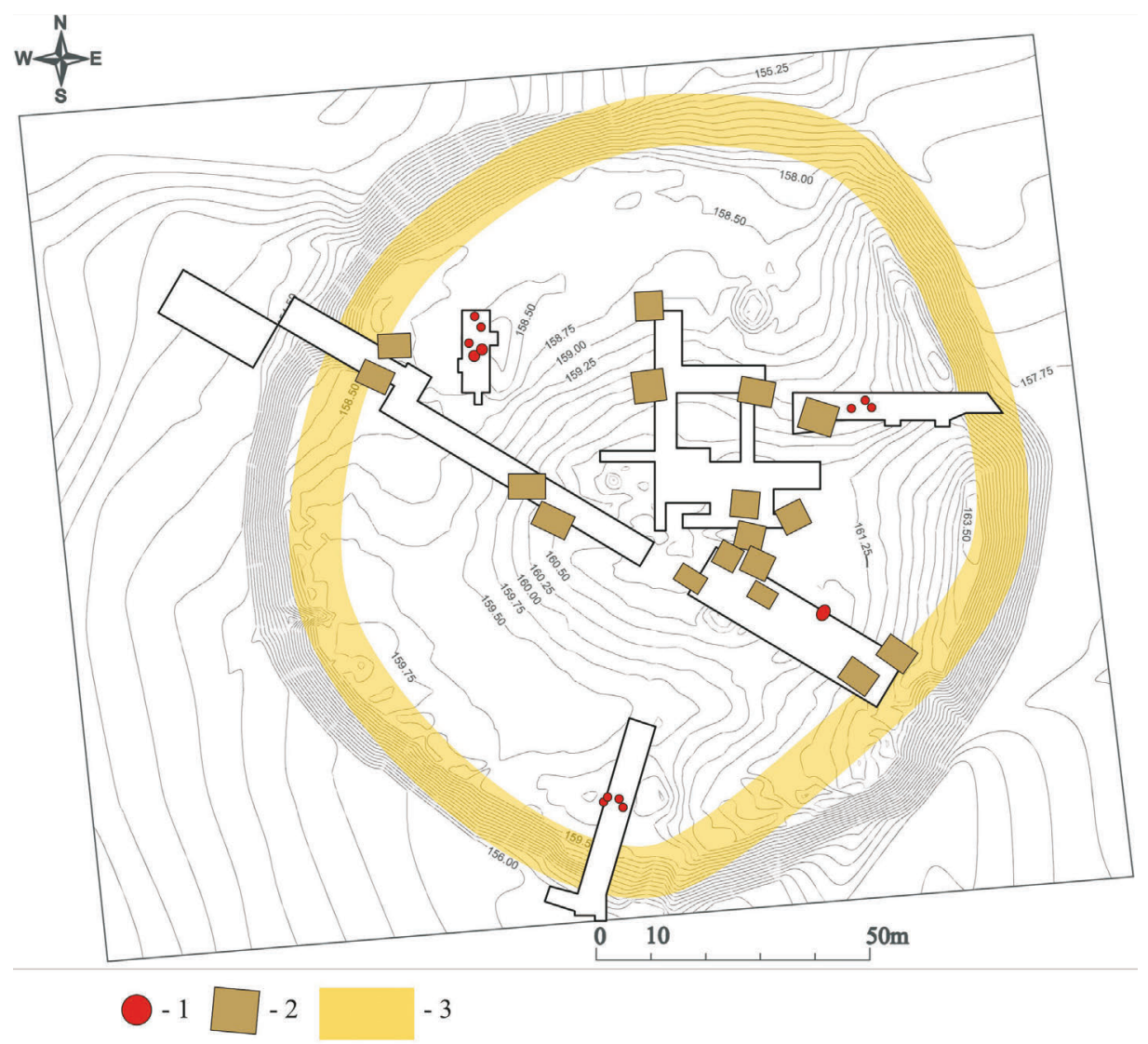

Ryc. 7. Grodzisko Piotrówka w Radomiu. Plan warstwicowy z lokalizacją obiektów datowanych na 2. połowę XIV - schyłek XV wieku. 1 - piece, 2 - relikty budynków szkieletowych, 3 - przebieg zniwelowanych wałów (oprac. M. Trzeciecki)

Fig. 7. Stronghold Piotrówka in Radom. Contour plan with location of features dated to the second half of the $14^{\text {th }}$ - the end of the $15^{\text {th }}$ century. 1 - kilns, 2 - remains of timber-framed buildings, 3 - course of levelled ramparts (edited by M. Trzeciecki)

osadzie hutniczej”, obecnej we wcześniejszych publikacjach. Zachowana dokumentacja z badań nie dostarczyła jednoznacznych przesłanek, umożliwiających określenie funkcji pieców, wskazuje natomiast na stosunkowo duże podobieństwo odkrytych wówczas obiektów, zarówno pod względem formy, jak i szczegółów konstrukcyjnych. Na jej podstawie można przypuszczać, że wszystkie opisane tu piece funkcjonowały na otwartym terenie.

Pośrednich przesłanek dotyczących funkcji pieców może dostarczyć analiza porównawcza. Zarówno ich forma, jak i technika budowy nie stanowią podstawy do wykluczenia ich związku z wytopem żelaza (Gassmann 2012). Pośrednio wskazują na nią wzmianki o dużych ilościach żużli żelaznych znajdowanych 
w ich kontekście. Jednak kwerenda zachowanych w Muzeum im. Jacka Malczewskiego w Radomiu materiałów źródłowych i zapisów w inwentarzach polowych wykazała, że informacje o występowaniu w obrębie pieców licznych żużli nie znajdują potwierdzenia. Odnotowano je jedynie w wykopie nr 1/1959, przy czym wystąpiły w zasypisku tylko jednego pieca (obiekt nr 5), wraz z równie licznymi fragmentami naczyń ceramicznych, gwoździami żelaznymi, szkłem okiennym i kośćmi zwierzęcymi. Żużle odnotowano także w przykrywającej konstrukcje „warstwie nr II”. Zaznaczyć tu należy, że owa „warstwa” to poziom eksploracji o miąższości przeszło $0,5 \mathrm{~m}$, a zebrany z niego materiał był metrykowany w odniesieniu do całego, liczącego ponad 1 ar powierzchni, wykopu. Trudno jest zatem ocenić, czy wspomniane żużle występowały w skupiskach, czy ich rozkład był równomierny. Ponieważ wśród znalezisk pochodzących z ,warstwy II” licznie występował redeponowany wczesnośredniowieczny materiał ceramiczny, można przypuszczać, że część żużli pochodziła ze starszych poziomów użytkowych grodziska. Udział żużli żelaznych w zbiorach znalezisk z pozostałych wykopów był niewielki i nie odbiegał od proporcji odnotowanych dla zespołów z ostatnio prowadzonych badań. Wydaje się więc, że dokonana w 1959 roku, niejako „na gorąco”, wstępna interpretacja funkcji dwóch pierwszych pieców została mechanicznie przeniesiona na kolejne obiekty. Uzupełniona zgodną z duchem czasu narracją o osadzie „hutników”, wegetujących w XIV wieku na ruinach siedziby „feudała”, utrwalona została w publikacjach (Fuglewicz 2013, s. 99-100).

Nie można wykluczyć związku analizowanych pieców z odlewnictwem metali nieżelaznych. Opisy niewielkich urządzeń ogniowych, przeznaczonych do przygotowania składników stopów czy nadawania surowcowi postaci płynnej przed wlaniem do formy, znajdujemy w średniowiecznych i nowożytnych źródłach (Teofil prezbiter 1998, s. 51-54; Agricola 2000, s. 452 i nn.). Obiekty o takim przeznaczeniu znamy też z badań wykopaliskowych, przede wszystkim ze średniowiecznych parcel miejskich (Krabath 2012, s. 118 i nn.). Bliską analogią do obiektów odkrytych w latach 60. na Piotrówce może być niewielki piec odlewniczy odsłonięty podczas badań na Placu Dominikańskim we Wrocławiu i wiązany z placem budowy klasztoru Dominikanów (Piszczałowski i in. 1993, s. 46-48). Z kolei piec z wykopu nr 8/2012 przypomina urządzenie do topienia metali, odkryte na Starym Mieście w Magdeburgu, datowane na XIV wiek (Adam, Stoll, Wilde 1990, s. 106-109). Podstawowym argumentem przemawiającym przeciw przypisaniu tej funkcji piecom z Piotrówki jest brak znalezisk odpadów poprodukcyjnych (żużli, bryłek stopionego metalu) oraz fragmentów tygli i form odlewniczych, zawsze towarzyszących takim urządzeniom (m.in. Adam, Stoll, Wilde 1990, s. 108 i nn.; König 2002, s. 148-149; Krabath 2002, s. 118 i nn.; Majewski 2013, s. 54-57 - w cytowanych pracach dalsza literatura). Z tych samych powodów trzeba też odrzucić możliwość identyfikacji obiektów z urządzeniami związanymi z produkcją szkła czy piecami garncarskimi. 
Biorąc pod uwagę powyższe ustalenia, należy poszukiwać związku opisywanych pieców z działalnością produkcyjną niepozostawiającą śladów uchwytnych dla archeologa. Już na wstępie trzeba wykluczyć utożsamianie obiektów z wyposażeniem kuźni. Dzięki prowadzonym w ostatnich latach badaniom średniowiecznych miast dysponujemy kilkoma stosunkowo dobrze rozpoznanymi pracowniami kowalskimi, z reguły wyposażanymi w otwarte, obudowane cegłami paleniska, pod względem formy i konstrukcji odległe od obiektów z Piotrówki (m.in. Muslow 2005; 2008 - w cytowanych pracach dalsza literatura). Podobnie mało prawdopodobne wydaje się uznanie opisywanych pieców za elementy infrastruktury browarów lub słodowni, choć ich formy i parametry mogą odpowiadać urządzeniom przeznaczonym do podgrzewania wody w kadziach. Należałoby bowiem oczekiwać śladów towarzyszących im innych obiektów niezbędnych w produkcji piwa, przede wszystkim pieców do suszenia słodu (m.in. Karst 2002, s. 23 i nn.; Dryja 2009, s. 194-197 - w cytowanych pracach dalsza literatura). Warto natomiast zwrócić uwagę na możliwość uznania obiektów z Piotrówki za piece piekarskie. Cylindryczne lub owalne urządzenia do wypieku chleba znamy z licznych przedstawień ikonograficznych (ryc. 8; por. też Perrine 1991). Obiekty takie były odkrywane również podczas badań wykopaliskowych, choć należy podkreślić, że ich identyfikacja jest zawsze problematyczna (m.in. Galioto 2012). Dobrą analogią może tu być kolisty piec piekarski z zamku Runding w Bawarii, pod względem wymiarów i formy identyczny z piecami odsłoniętymi na Piotrówce w latach 60. XX wieku (Herdick, Kühtreiber 2008, s. 54-56).

Najsłabszym punktem proponowanej tu identyfikacji jest brak możliwości potwierdzenia lub zanegowania tej funkcji na podstawie form, technik konstrukcji czy znalezisk. Pewną przesłankę skłaniającą do przyjęcia tej hipotezy może stanowić szerszy kontekst, zarówno archeologiczny, jak i historyczny, wskazujący na nowe możliwości interpretacji funkcji nie tylko pieców, ale i całej Piotrówki u schyłku średniowiecza.

Między połową XIV a schyłkiem XV wieku miał miejsce w dziejach Radomia niezwykle istotny okres, bardzo słabo udokumentowany w źródłach pisanych. Na połowę XIV wieku przypadała, przeprowadzona przez Kazimierza Wielkiego, reorganizacja przestrzenna całego ośrodka osadniczego, której najważniejszymi elementami była lokacja Nowego Radomia około 1 km na wschód od starego centrum osadniczego i przeniesienie siedziby kasztelana z grodu na Piotrówce do zamku wybudowanego wraz z fortyfikacjami nowego miasta (Szczygieł 2001, s. 24-28). Z początkiem XV wieku zamek radomski awansował do rangi jednej z najczęściej odwiedzanych rezydencji królewskich, a po połowie tego stulecia był miejscem obrad sejmów walnych i ważnych wydarzeń związanych z polityką zagraniczną i dynastyczną Jagiellonów. Częstotliwość wizyt królewskich wyraźnie osłabła dopiero za panowania dwóch ostatnich Jagiellonów (Kupisz 2009, s. 66 i nn. - tam dalsza literatura). 


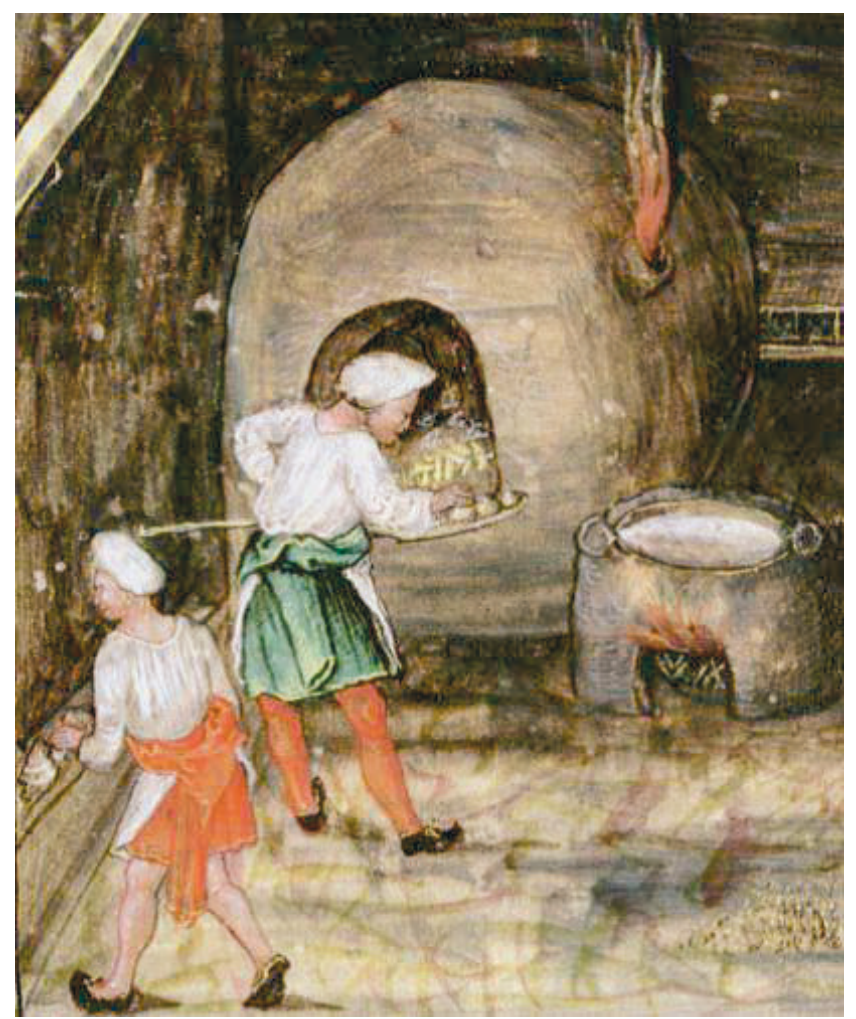

Ryc. 8. Piekarnia - miniatura z Kodeksu Behema (wg Fabiański 2000)

Fig. 8. Bakery - miniature from Behem Codex (after Fabiański 2000)

W tym kontekście można podjąć próbę nowego spojrzenia na późnośredniowieczną fazę użytkowania grodziska. Pojawienie się tam stosunkowo gęstej zabudowy, wznoszenie obszernych, podpiwniczonych budynków szkieletowych, charakterystycznych w owym czasie dla budownictwa miejskiego lub folwarcznego, wreszcie znaleziska militariów, oporządzenia końskiego i ozdób stroju mogą wskazywać, że na Piotrówce znajdowało się wówczas - przeniesione z terenu zamku - zaplecze gospodarcze (a może i „lokalowe”) dla regularnych pobytów rodziny królewskiej i dworu, obradujących w mieście sejmów, posiedzeń trybunału czy wizyt zagranicznych dyplomatów. Hipoteza ta jest oczywiście trudna do udowodnienia, bowiem nie zachowały się żadne wzmianki o Piotrówce w kontekście politycznych i rezydencjonalnych funkcji Radomia. Warto jednak podkreślić, że brakuje w ogóle źródeł pisanych, pozwalających zlokalizować gospodarcze zaplecze zamku w tym okresie. Pierwsza lustracja zamku radomskiego pochodzi dopiero z 1544 roku i opisuje zabudowania folwarku położonego wówczas w bezpośrednim sąsiedztwie zamku, oddzielonego linią murów miejskich i fosą (Guldon 1995, s. 183-186; Lechowicz 2012, s. 41-42). Grodzisko na Piotrówce 
wzmiankowane jest po raz pierwszy w 1522 roku: w potwierdzeniu darowizny dla kościoła parafialnego w Nowym Radomiu wymieniona jest łąka in Antiqua Radom, post montem et ecclesiam st. Petri penes prata plebani ibidem in Antiqua Radom consistencia (Wyrozumska 1984, s. 25). Jak wskazują dane archeologiczne, w tym czasie zabudowania na grodzisku już nie funkcjonowały.

Jeśli zatem przyjmiemy proponowaną tu hipotezę, umieszczającą na Piotrówce folwark zamkowy wybudowany w XV wieku w związku z awansem Radomia do roli jednej z rezydencji królewskich, zyskamy argument uzasadniający funkcjonowanie dużego zespołu pieców piekarskich, niezbędnych do zaopatrywania dworu, urzędników królewskich i gości w produkty spożywcze. Odnosi się to przede wszystkim do urządzeń odkrytych w latach 60. XX wieku, bardzo do siebie zbliżonych pod względem formy i funkcji. Kwestia interpretacji odróżniającego się nieco pieca odkrytego w 2012 roku pozostaje otwarta, choć także w jego przypadku najbardziej wiarygodny pozostaje związek z przetwórstwem produktów spożywczych. Zagadnienia funkcji opisywanych tu obiektów, jak i miejsca Piotrówki w gospodarczej i społecznej topografii XV-wiecznego Radomia, są jeszcze dalekie od ostatecznego rozstrzygnięcia. Wydaje się jednak, że zarówno nowe odkrycia, jak i powrót do wyników starszych badań, w połączeniu z analizą danych historycznych, pozwalają ostatecznie pożegnać się z wizją „ubogiej osady hutniczej”, na ruinach dawnego kasztelańskiego grodu.

Na zakończenie warto podkreślić, że choć zaprezentowane tu wyniki pozwalają wiązać piece odkryte na Piotrówce z zapleczem gospodarczym zamku radomskiego, to ani analiza form i konstrukcji obiektów, ani przegląd znalezisk czy materiał porównawczy nie przyniosły jednoznacznych odpowiedzi na pytanie o funkcję, jaką pełniły. Ich związek z wypiekiem chleba wydaje się najbardziej prawdopodobny, wskazuje na niego jednak wyłącznie analiza szerszego kontekstu archeologicznego i historycznego znalezisk. Co więcej, wydaje się niemal pewne, że obiekty o zbliżonej formie i rozwiązaniach konstrukcyjnych mogły mieć bardzo szerokie zastosowanie. Piece z Piotrówki stanowią znakomity przykład złożoności problematyki badań obiektów uznawanych za pozostałości warsztatów i towarzyszących im śladów aktywności ludzkiej.

\section{Literatura}

Wykaz skrótów

Mittelalterliche Öfen - Mittelalterliche Öfen und Feuerungsanlagen. Beiträge des 3. Kolloquiums des Arbeitskreises zur archäologischen Erforschung des mittelalterlichen Handwerks, red. R. Röber, Materialhefte zur Archäologie in Baden-Württemberg 62, Stuttgart 
Adam K., Stoll H.-J., Wilde P.-M.

1990 Zum mittelalterlichen Bunt- und Edelmetallguss in Magdeburg, Zeitschrift zur Archäologie, t. 24, s. 101-122.

Agricola G.

2000 O górnictwie i hutnictwie dwanaście ksiag, tłumacz. K. Kurková, Jelenia Góra.

Auch M., Bugaj U., Trzeciecki M.

2012 Archeologia w Radomiu - archeologia dla Radomia. Próba podsumowania pierwszych lat projektu „Park Kulturowy Stary Radom”, [w:] Archeologia w obliczu wyzwań wspótczesności, Radom. Korzenie miasta i regionu, t. 3, red. A. Buko, D. Główka, M. Trzeciecki, Warszawa, s. 9-40.

Auch M., Solarska K., Trzeciecki M.

2013 Badania wykopaliskowe w sezonie 2013 na stanowisku nr 1 - grodzisko „Piotrówka” w Radomiu, maszynopis w archiwum Instytutu Archeologii i Etnologii PAN, Warszawa.

Auch M., Trzeciecki M.

2011 Relikty umocnień obronnych odkrytych $w 2010$ roku na stanowisku 1 w Radomiu, [w:] Radomski zespót osadniczy w dolinie rzeki Mlecznej. Wyniki badań interdyscyplinarnych 2010 r., Radom. Korzenie miasta i regionu, t. 2, red. A. Buko, D. Główka, M. Trzeciecki, Warszawa, s. 35-69.

Dryja S.

2009 Technologia produkcji słodowniczej i piwowarskiej w średniowieczu i na poczqtku ery nowożytnej w Krakowie, Archaeologia Historica Polona, t. 18, s. 185-208.

Fabiański M.

2000 Miniatury z Kodeksu Baltazara Behema, Kraków.

Fuglewicz B.

2013 Poczatki Radomia. Wczesnośredniowieczny zespół osadniczy nad rzeka Mleczna, Radom.

Galioto L.

2012 Eine mittelalterliche Bäckerei in Freiburg, [w:] Mittelalterliche Öfen, s. $97-100$.

Gassmann G.

2012 Mittelalterliche Eisenerverhüttungsanlagen in Baden-Würtemberg, [w:] Mittelalterliche Öfen, s. 27-34.

Guldon Z.

1995 Źródła do dziejów Radomia, [w:] Osadnictwo i gospodarka powiatu radomskiego w XVI-XVIII wieku, Radom i region radomski w dobie szlacheckiej Rzeczypospolitej 1, red. Z. Guldon, S. Zieliński, Radom, s. 180-195.

Herdick M., Kühtreiber T.

2008 Burgen, Handwerk und Gewerbe - Ammerkungen zum Forschungsstand, [w:] Archäologie und mittelalterliches Handwerk - Eine Standortbestimmung. Beiträge des 10 Kolloquiums des Arbeitskreises zur archäologischen Erforschung des mittelalterlichen Handwerks, red. W. Melzer, Soest, s. 37-60. 
Karst D.

2002 Technologia rzemieślniczej produkcji piwa we Wrocławiu w okresie średniowiecznym i nowożytnym na tle browarnictwa europejskiego, [w:] Piwo we Wrocławiu od średniowiecza po czasy współczesne, red. H. Okólska, Wrocław, s. 9-45.

Kierzkowska-Kalinowska E.

1963 Sprawozdanie z badań Terenowej Ekspedycji Wykopaliskowej IHKM PAN w Radomiu przeprowadzonych w roku 1962, maszynopis w archiwum Muzeum im. Jacka Malczewskiego w Radomiu, Radom.

$1966 \quad$ Sprawozdanie $z$ prac terenowych prowadzonych $w$ Radomiu w latach 1959-1964, Sprawozdania Archeologiczne, t. 18, s. 207-218.

1970 Dziesięć lat badań Ekspedycji Wykopaliskowej IHKM PAN w Radomiu, Biuletyn Kwartalny Radomskiego Towarzystwa Naukowego, t. 7, z. 1-2, s. 39-68.

1971 Stanowisko 1, wykop 4. Badania 1970, maszynopis w archiwum Muzeum im. Jacka Malczewskiego w Radomiu, Radom.

1973 Opis warstw kulturowych w poszczególnych wykopach archeologicznych na Starym Mieście w Radomiu, maszynopis w archiwum Muzeum im. Jacka Malczewskiego w Radomiu, Radom.

1979 Rozwój procesów osadniczych na obszarze Radomia przed lokacja miasta, [w:] Urbanistyka i architektura Radomia, red. W. Kalinowski, Lublin, s. 9-44.

Kierzkowska E., Kierzkowski K.

1960 Sprawozdanie z badań przeprowadzonych w roku 1959 na grodzisku „Piotrówka” w Radomiu, maszynopis w archiwum Muzeum im. Jacka Malczewskiego w Radomiu, Radom.

König S.

2002 Untersuchungen zur Gusstechnik mittelalterlicher und neuzeitlicher Glocken aufgrund archäologisches Befunde in Europa, [w:] Mittelalterliche Öfen, s. 143-163.

Krabath S.

2002 Die mittelalterlichen Buntmetallschmelzöfen in Europa. Vergleichende Studien aufgrund archäologischer, schriftlischer und ikonografischer Quellen, [w:] Mittelalterliche Öfen, s. 115-142.

Kupisz D.

2009 Radom w czasach Jagiellonów (1386-1572), Warszawa.

Lechowicz Z.

2012 Zamek w Radomiu. Archeologia i architektura. Badania i interpretacje, Radom.

Majewski M.

2013 Późnośredniowieczny warsztat ludwisarski odkryty na kwartale IX w Stargardzie, [w:] XVII Sesja Pomorzoznawcza, t. 2: Od późnego średniowiecza do czasów nowożytnych, red. H. Paner, M. Fudziński, Gdańsk, s. 45-69. 
Muslow R.

2005 Eisenverarbeitung und Eisenschmieden, [w:] Archäologie unter dem Strassenpflaster. 15 Jahre Stadtkernarchäologie im Mecklemburg-Vorpommern, red. J. Stanke, F. Lüth, H. Schäfer, Schwerin, s. 301-310.

2008 Ein Schmiedengrundstück in der Wollenweberstrasse 33 in Rostock, Archäologische Berichte au Meclemburg-Vorpommern, t. 15, s. 91-106.

Perrine M.

1991 Images de panification au Moyen Âge, [w:] La préparation alimentaire des cérealés: rapports présentés à la table ronde organiseé à Ravello au Centre univeristaire européen pour les biens culturels du 11 au 14 avril 1988, red. F. Sigaut, D. Fournier, Strasbourg, s. 51-68.

Piszczałowski W., Lissak Z., Karst M., Zaleski S.

1993 Sprawozdanie z badań w obrębie dawnych posesji plac Dominikański nr 3, 5, 7/9 oraz Zaułek Niski nr 6, 8, 10, 12, Silesia Antiqua, t. 35, s. 35-39.

Szczygieł R.

2001 Powstanie nowego miasta w Radomiu, [w:] Radom. Lokacja miasta, odkrywanie zamku, red. S. Piątkowski, Radom, s. 24-32.

Teofil Prezbiter

1998 Teofil Prezbiter. Diversarum Artium Schedula. Średniowieczny zbiór przepisów o sztukach rozmaitych, tłumacz i oprac. S. Kobielus, Kraków.

Trzeciecki M.

2013 Projekt „Park Kulturowy Stary Radom” - badania Instytutu Archeologii i Etnologii PAN w latach 2009-2012, [w:] Piotrówka. Pamięć rodowodu. Katalog wystawy, Muzeum im. Jacka Malczewskiego w Radomiu, styczeń-grudzień 2013, red. E. Skubicha, M. Kwiatkowska-Rzodeczko, Radom, s. 23-39.

2015 Gród radomski na pograniczu Małopolski i Mazowsza - zarys problematyki badawczej, [w:] Grody średniowiecznego Mazowsza. Księga poświęcona pamięci Marka Dulinicza, red. M. Żurek, M. Krasna-Korycińska, Warszawa, s. 181-201.

Trzeciecki M., Solarska K.

2013 Grodzisko Piotrówka w Radomiu - badania w sezonie 2012, [w:] Ziemia niczyja - ziemia nieznana. Schyłek starożytności i średniowiecze na ziemiach między Wisła a Pilicq, Radom. Korzenie miasta i regionu, t. 4, red. A. Buko, Wyrozumska B.

D. Główka, M. Trzeciecki, Warszawa, s. 47-76.

1984 Dokumenty miasta Radomia z lat 1444-1611, Biuletyn Kwartalny Radomskiego Towarzystwa Naukowego, t. 21, z. 4, s. 16-74. 


\section{LATE MEDIEVAL PRODUCTION KILNS FROM STRONGHOLD PIOTRÓWKA IN RADOM - POSSIBILITIES OF INTERPRETATION}

Summary

During excavations conducted in the 1960s on stronghold Piotrówka in Radom, remains of 12 kilns similar to each other in terms of form and structure were discovered. They were oval in plan, the chambers' diameters were about $1.5 \mathrm{~m}$, the thickness of walls formed from layers of clay and stones $0.3-0.4 \mathrm{M}$. Most likely they functioned in open space. Due to the fact that during the aforementioned excavations the main subject of interest were early medieval occupation levels, these features were documented fairly briefly. The discoverers determined their chronology as the end of the Middle Ages and considered them as remains of iron smelting furnaces. The entire assemblage was supposed to be the remains of a 'poor metallurgical settlement', created on the abandoned $14^{\text {th }}$-century stronghold.

The relics of the next kiln were found during the excavations conducted in 2010-2013. It was oval in plan with diameter of 1.5-1.8 m, clay floor and walls were made of bricks bonded with clay and covered with stones. Like features from previous excavations, it can be dated to the second half of the $14^{\text {th }}-15^{\text {th }}$ centuries and linked to the period after the stronghold abandonment. Within the kiln and its surroundings, there were no signs clearly showing the relationship to the iron smelting, hence the issue of interpreting the function of the kilns remained open. At the same time, the context in which these features occurred - the relics of several large timber-framed buildings, numerous finds of spurs, elements of weaponry, coins - made questionable the thesis on the 'poor metallurgical settlement' already established in the literature.

The research on finds from the surroundings of the other kilns was carried out. Its results do not provide a basis for linking these features with iron smelting. Comparative analysis of forms and construction technique of kilns from Piotrówka also does not give a clear answer to the question about their function. Simple, circular in plan fire devices were used in many craft branches. The of finds of production waste rules out the relationship of kilns in question with metal or glass processing. Most likely, they served as bakery ovens and were part of the economic background of the Radom castle, which in the $15^{\text {th }}$ century was one of the most important royal residences, a place of parliament debates and political decision-making. With the daily service of political events, attracting hundreds of visitors to Radom, were probably associated the buildings erected at that time on the stronghold, as well as the kilns in question.

The Radom kilns are an excellent example of the complexity of research on traces of old production, complicated particularly due to state of preservation of features considered as remains of workshops and the accompanying traces of human activity. 
